\title{
A Brief Discussion on the Impediment and Resolution of Individual Income Tax
}

\author{
Wenxuan $\mathrm{Yao}^{1, *}$ \\ ${ }^{1}$ Business School, Sichuan University, Chengdu, Sichuan, China \\ *Corresponding author.Email: wenxuany5@qq.com
}

\begin{abstract}
Since the new adjustment in 2018, the personal income tax threshold is still hotly discussed. This paper believes that there are few deductions items, low deductions amount, frequent adjustments to the threshold, and the growth rate of taxpayers' personal income tax is higher than the GDP growth rate over the same period, which inhibits the momentum of personal tax on consumption. After reviewing the critical value of previous adjustments to the threshold, it is recommended to expand the deduction items, increase the deduction amount, and pay full attention to the legislative foresight and stability.
\end{abstract}

Keywords: Personal income tax, Deduction, Legislative foresight.

\section{INTRODUCTION}

Since the personal income tax reform in 2018, the fact has not changed, that personal income tax has been reduced to payroll tax. Academia and industry have conducted extensive discussions on this. A well-known domestic entrepreneur advocated that the threshold should be increased to 20,000 Yuan. Under the dual-cycle pattern, the adjustment function of personal income tax should be emphasized, the marginal consumption effect of currency should be improved, and consumption vitality should be released.

\section{ENERGY CONVERSION OF PERSONAL INCOME TAX UNDER THE NEW PATTERN}

The function of personal income tax has always been two propositions: income theory and adjustment theory. The income theory emphasizes that personal income tax is an important source of national fiscal revenue, and the adjustment theory emphasizes that personal income tax is used to regulate social income distribution. Objectively, personal income tax has both functions, but it has its own emphasis in different periods. As Sino-US relations continue to enter a difficult period, the external economic environment is unfavorable and exports are declining. China has proposed a dual- cycle development approach to boost domestic demand. However, Huang Dazhi's research shows that China's consumption is far from enough for economic growth. When he investigated China's consumption level, he referred to three categories of countries. The first category is developed countries such as the United States, Japan and South Korea, the second category is countries with similar GDP per capita such as Russia, Brazil, and Poland, and the third category is countries such as India, Thailand, Vietnam and other emerging market countries adjacent to China. Huang Dazhi found that whether it is compared with high-level developed countries, or compared with the same level of per capita GDP development, or neighboring countries with similar cultural and geography, China's final consumption rate is very low, and compared to the same level for countries with per capita GDP, it is about $25 \%$ lower. After deducting government consumption of the resident consumption rate, the consumption level gap between China and other countries will be reduced to about $20 \%$, but it is still the lowest among countries with the same level and neighboring countries. At the same time, since 1994, China's Gini coefficient has exceeded the international warning line of 0.4 for a long time and close to 0.5 in a few years. The problem of uneven income distribution is prominent. In this context, a proactive fiscal policy should be adopted, focusing on the adjustment function of personal income tax, 
realizing energy conversion, and promoting consumption from reducing the tax burden of residents and narrowing the social income gap, making it an important driving force for economic growth.

\section{THE KINETIC ENERGY BLOCK OF PERSONAL INCOME TAX}

China's personal income tax has been revised 9 times, and the personal income tax threshold has been adjusted four times. The most recent one was in 2018. The threshold and tax rate have been adjusted, especially considering the children's education, support for the elderly, and housing mortgage deduction. The threshold was raised from 3,500 yuan in the 2011 version to 5,000 yuan, plus deductions, it can be understood that the threshold is adjusted to a maximum of 8,000 yuan, but this adjustment, the momentum of personal income tax on consumption has not been fully released. The reason for the blockade is that the deduction is unreasonable from a micro perspective; from a macro perspective, the legislation lacks forwardlooking.

\subsection{The Current Personal Income Tax Deduction Is Unreasonable}

Food, clothing, housing and transportation are the most basic survival needs of taxpayers, and supporting the elderly and raising children is the most basic social obligation of taxpayers. First of all, the mortgage deduction for housing is unreasonable. A family of three with a living area of 60 square meters and two small houses, calculated at 10,000 yuan per square meter, the total house price is 600,000 yuan, the down payment is 200,000 yuan, the mortgage is 400,000 yuan for 10 years, the monthly repayment is about 4,000 yuan, and the personal income tax deduction is 1,000 Yuan is obviously unreasonable. Secondly, the deduction for supporting the elderly is unreasonable. In rural areas, the government subsidy is up to 200 yuan per month for elderly people over 60 years old, 800 yuan for four elderly people, a couple of single couples deduct 1,000 yuan, and a monthly living allowance of 1800 yuan for four elderly people, an average of 450 yuan per person per month. Living in the rural is not enough, let alone living in the city. Considering that children still need to support the elderly with insufficient public medical care, the deduction is obviously too low. Third, the deduction for raising children is also low. Food expenditures, medical expenditures, childcare expenditures, education expenditures, etc. are added together, so 1,000 yuan deduction is not enough.

\subsection{The Adjustment of the Personal Income Tax Threshold Is Not Forward-looking}

The tax threshold is the basic point of individual income tax legislation, and it is also the content that is most likely to attract taxpayers' attention. The adjustment of the threshold should not only closely follow the current income growth of taxpayers, but also reasonably predict the expected income of taxpayers based on the growth rate of national income. As shown in "Table 1", except for the following year after the threshold is adjusted, in other years, the annual growth rate of per capita tax paid by urban employees was much higher than that of GDP growth in the same period. The threshold adjustment is used to increase the disposable income of residents, thereby releasing the original intention of the reform of the potential of domestic demand has never been reflected, and the kinetic energy of personal income tax to boost demand within China has been completely suppressed, indicating that the forward-looking adjustment of the threshold is not enough. 
Table 1. Per capita personal Income tax of urban employees and its growth rate

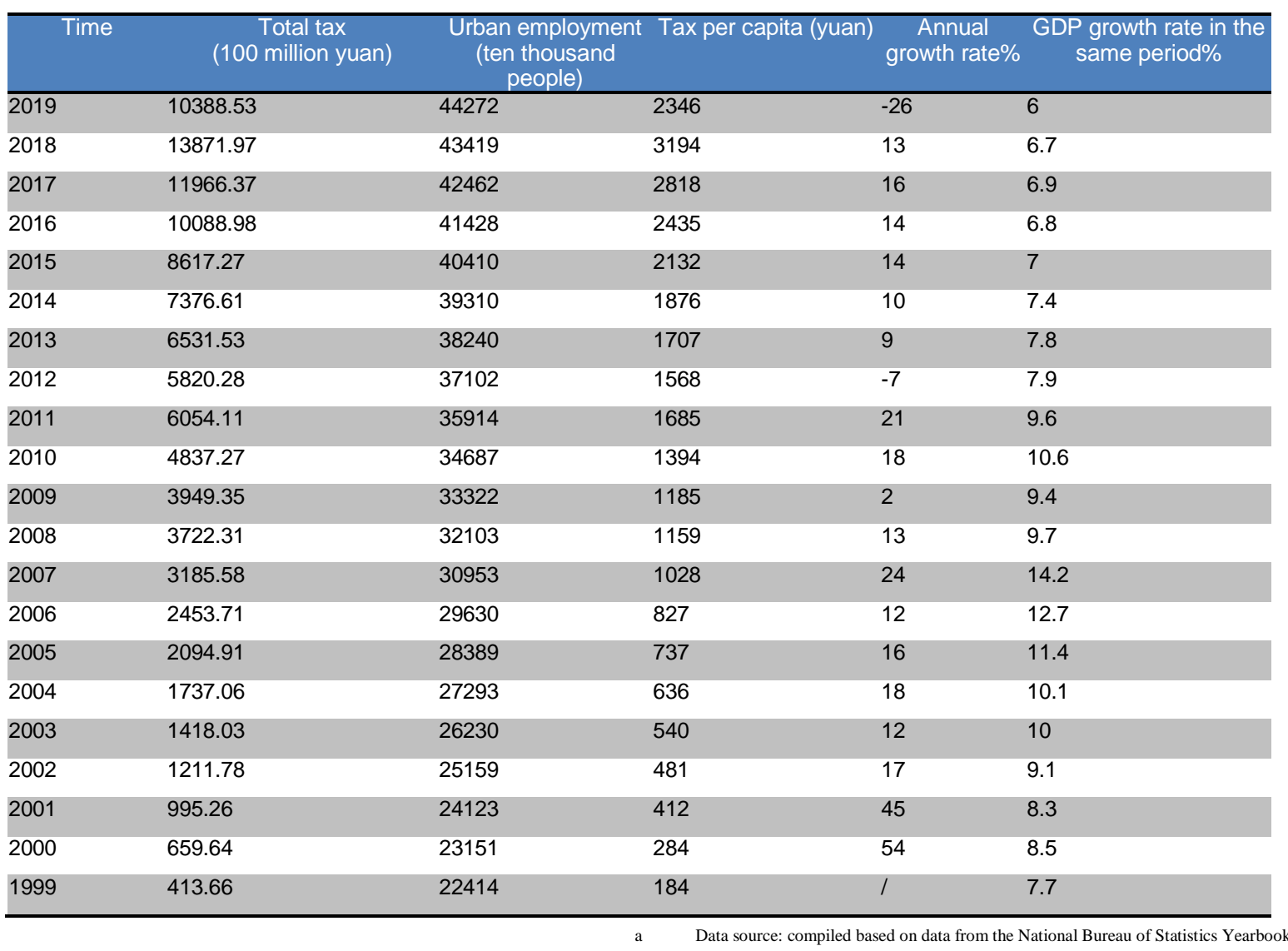

The threshold adjustment is not sufficiently forward-looking, not only reflected in the excessive growth of per capita personal tax, but also in the excessively frequent adjustment of the threshold. As shown in "Table 2", the first interval is 9 years, the second interval is 2 years, and the third interval is 3.5 years. Adjustments are needed in just 2 or 3 years, indicating that the adjustment of the threshold is not forward-looking and also affects the stability of the law and increases the cost of social governance. Although the fourth time interval is slightly longer, it is 7 years, but compared with the critical points of the previous adjustments ("Table 3"), the new adjustment threshold in 2018 still has the same problem. 
Table 2. China's previous personal income tax threshold adjustments

\begin{tabular}{|l|l|l|l|l|}
\hline \multicolumn{1}{|c|}{ Number } & Time & \multicolumn{1}{|c|}{ Content } & Threshold & Time interval \\
\hline 1 & 1980.9 .10 & $\begin{array}{l}\text { Promulgated the "Individual Income Tax Law of the } \\
\text { People's Republic of China" }\end{array}$ & \\
\hline 2 & 1986.9. & $\begin{array}{l}\text { "Interim Regulations on Personal Income Regulation Tax } \\
\text { of the People's Republic of China" (Individual Income of } \\
\text { National Citizens) }\end{array}$ & 800 yuan & \\
\hline 3 & 1993.10 .31 & $\begin{array}{l}\text { "Decision on Amendments" (The income of national and } \\
\text { non-national citizens in China) }\end{array}$ & \\
\hline 4 & 1999.8 .30 & $\begin{array}{l}\text { Decision on Amending the "Individual Income Tax Law of } \\
\text { the People's Republic of China" (Individual savings } \\
\text { deposit interest is subject to individual tax) }\end{array}$ & \\
\hline 5 & 2002.1 .1 & $\begin{array}{l}\text { Individual income tax revenue is shared proportionally } \\
\text { between the central and local governments }\end{array}$ & \\
\hline 6 & 2005.10 .27 & "Draft Amendment to the Individual Income Tax Law" & 1600 yuan & 9 years \\
\hline 7 & 2007.12 .29 & "Decision on Amending the Individual Income Tax Law" & 2000 yuan & 2 years \\
\hline 8 & 2011.6 .30 & & 3500 yuan & 3.5 years \\
\hline 9 & 2018.8 .31 & & 5000 yuan & 7 years \\
\hline
\end{tabular}

Data source: compiled based on data from the National Bureau of Statistics Yearbook.

When the monthly personal income tax payment accounts for more than $3.5 \%$ of the per capita monthly income of urban employees, the tax threshold needs to be adjusted. Compared with 2018, the annual per capita monthly income will increase by $10 \%$ in 2019 . According to this growth rate, the average annual monthly income of urban employees in 2020 is expected to reach 8,559, which will exceed the maximum deduction of 8,000 yuan, 559 yuan. From 2018 to 2020, in just two years, the monthly personal income tax payment has accounted for $4.15 \%$ of urban employees' per capita monthly income, which has far exceeded the previous adjusted standard line of 3.5\%. ("Table 3")

Table 3. Per capita monthly income and personal income tax amount from 1986 to 2020

\begin{tabular}{|c|c|c|c|c|c|c|}
\hline time & $\begin{array}{l}\text { Threshold } \\
\text { (X) }\end{array}$ & $\begin{array}{l}\text { Total annual } \\
\text { salary of } \\
\text { employees }\end{array}$ & $\begin{array}{c}\text { Monthly salary } \\
\text { of employees } \\
\text { in the same } \\
\text { period }(Y)\end{array}$ & $\begin{array}{l}\text { Taxable } \\
\text { income } \\
(Y-X)\end{array}$ & $\begin{array}{l}\text { Personal } \\
\text { income tax } \\
\text { amount } \\
(\mathrm{Z})\end{array}$ & $\begin{array}{c}\text { Tax burden } \\
\text { percentage of } \\
\text { monthly income } \\
(\mathrm{Z} / \mathrm{Y}) \%\end{array}$ \\
\hline 1986.9 .10 & 800 & 1721 & 106 & -736 & 0 & \\
\hline 1987 & & 1459 & 122 & -678 & 0 & \\
\hline 1988 & & 1764 & 147 & -653 & 0 & \\
\hline 1989 & & 1935 & 161 & -639 & 0 & \\
\hline 1990 & & 2140 & 178 & -622 & 0 & \\
\hline 1991 & & 2340 & 195 & -605 & 0 & \\
\hline 1992 & & 2711 & 226 & -574 & 0 & \\
\hline 1993 & & 3371 & 281 & -519 & 0 & \\
\hline 1994 & & 4538 & 378 & -422 & 0 & \\
\hline 1995 & & 5560 & 458 & -342 & 0 & \\
\hline 1996 & & 6210 & 518 & -282 & 0 & \\
\hline 1997 & & 6470 & 539 & -261 & 0 & \\
\hline 1998 & & 7479 & 623 & -177 & 0 & \\
\hline 1999 & & 8346 & 696 & -104 & 0 & \\
\hline 2000 & & 9371 & 781 & -19 & 0 & \\
\hline 2001 & & 10870 & 906 & 106 & 5.3 & 0.58 \\
\hline 2002 & & 12422 & 1035 & 235 & 11.5 & 1.1 \\
\hline 2003 & & 14037 & 1170 & 370 & 17.5 & 1.2 \\
\hline time & $\begin{array}{l}\text { Threshold } \\
(X)\end{array}$ & $\begin{array}{l}\text { Total annual } \\
\text { salary of } \\
\text { employees }\end{array}$ & $\begin{array}{c}\text { Monthly salary } \\
\text { of employees } \\
\text { in the same } \\
\text { period }(Y)\end{array}$ & $\begin{array}{c}\text { Taxable } \\
\text { income } \\
(Y-X)\end{array}$ & $\begin{array}{l}\text { Personal } \\
\text { income tax } \\
\text { amount } \\
(Z)\end{array}$ & $\begin{array}{l}\text { Tax burden } \\
\text { percentage of } \\
\text { monthly income } \\
(\mathrm{Z} / \mathrm{Y}) \%\end{array}$ \\
\hline 2004 & & 16024 & 1335 & 535 & 53.5 & $\underline{4.0}$ \\
\hline 2005 & & 18364 & 1530 & 730 & 73.0 & $\underline{4.8}$ \\
\hline
\end{tabular}




\begin{tabular}{lllllll}
\hline 2006.1 .1 & 1600 & 21001 & 1750 & 150 & 7.5 & 0.42 \\
2007 & & 24932 & 2078 & 478 & 24 & 1.15 \\
2008.3 .1 & 2000 & 29229 & 2436 & 436 & 21.8 & 0.9 \\
2009 & & 32736 & 2728 & 728 & 72.8 & 2.7 \\
2010 & & 37147 & 3096 & 1096 & 109.6 & $\underline{3.5}$ \\
2011.9 .1 & 3500 & 42452 & 3538 & 38 & 1.14 & 0.03 \\
2012 & & 47593 & 3897 & 397 & 19.9 & 0.30 \\
2013 & & 51474 & 4290 & 790 & 23.7 & 0.55 \\
2014 & 56339 & 4695 & 1195 & 35.8 & 0.76 \\
2015 & 61240 & 5103 & 1603 & 160 & 3.13 \\
2016 & 68993 & 5749 & 2249 & 225 & $\underline{3.91}$ \\
2017 & & 76121 & 6343 & 2543 & 254 & $\underline{4.0}$ \\
2018.10 .1 & $5000(8000)$ & 84744 & 7062 & $2062 /(-938)$ & $62 /(0)$ & 0.8 \\
2019 & & 93383 & 7781 & $2781 /(-219)$ & $83 /(0)$ & 1.06 \\
2020 (estimated) & & 8559 & $3559 / 559$ & $356 / 16.8$ & $\underline{4.15 / 0.2}$ \\
\hline
\end{tabular}

\section{WAYS TO STRENGTHEN THE KINETIC ENERGY OF PERSONAL INCOME TAX}

\subsection{Determining Reasonable Deductions and Deductions Based on Actual Consumption Needs}

The report of the 19th National Congress of the Communist Party of my country pointed out that the main contradiction in our society in the new era is the contradiction between the people's growing need for a better life and unbalanced and inadequate development. The connotation of a good life is by no means limited to food and clothing, but requires citizens to have the ability to obtain the private or public goods necessary to sustain life and ensure safety, health and freedom, as well as spiritual material guarantees including cultural and recreational facilities. In addition to the current expenses for child support and housing loans for the elderly, personal income tax deductions also include residents' daily travel, holiday outings, essential clothing expenses, cultural and entertainment expenses, etc. In addition, in order to adapt to the ever-increasing social needs, taxpayers' vocational training and self-education expenditures are also essential. Based on actual expenditures, expand personal income tax deductions, increase the amount of current deductions, increase residents' actual disposable income, stimulate personal income tax momentum, and boost domestic demand.

\subsection{Paying Attention to Legislation Foresight}

The promulgation of the law requires a series of processes such as organizing research, investigating public opinion, collecting information, formulating plans, discussing and modifying, and then in the implementation process also requires publicity and explanation, learning and training, etc., which requires a lot of organizational costs, legislative costs, and adjustment costs. The personal income tax threshold needs to have a reasonable forecast of the taxpayer's annual income based on the growth rate of national income. On this basis, the threshold must be determined scientifically and maintained for a long period of time, emphasizing the stability and forward-looking nature of tax legislation. Save costs from the formulation and implementation of laws, and promote the modernization of the national governance system and governance capabilities.

\section{CONCLUSION}

With few item and lower quota of deduction than actual living expenses, just two years after the new reform of personal income tax, the tax burden of urban employees in income has greatly exceeded the adjustment threshold of 3.5. The effect of vitality is greatly reduced, which reform personal income tax releases consumption. Therefore, the personal income tax reform needs to increase the deduction items and raise the threshold based on the actual living expenses of residents, so as to effectively increase the consumption power of the 
low- and middle-income class and strengthen the multiplier effect of consumption.

\section{AUTHORS' CONTRIBUTIONS}

This paper is independently completed by Wenxuan Yao.

\section{REFERENCES}

[1] Huang Dazhi. What is the level of consumer consumption in China in the world? China Economic Information Network, March 29, 2021.

[2] Zhang Xu. Rethinking and improvement of special additional deduction rules for personal income tax. Taxation and Economy [J], 2020/5.

[3] Liu Chenglong. Optimization of my country's personal income tax from the perspective of national governance. Taxation Research $[\mathrm{J}]$, 2020/2.

[4] Tang Jieyin. The protection and realization mechanism of the basic rights of taxpayers: with personal income tax as the core. China Law Review [J], 2018/6.

[5] Yue Shumin, Liu Xinyu. The functional positioning and reform of my country's personal income tax $[\mathrm{J}]$. International Taxation, 2018(7).

[6] Feng Ximing. The choice of personal income tax system from a fair perspective [J]. Accounting Research, 2009(5). 